ORIGINAL ARTICLE / ARTIGO ORIGINAL

\title{
Agreement on underlying causes of infant death between original records and after investigation: analysis of two biennia in the years 2000
}

\author{
Concordância sobre causas básicas de morte infantil entre registros \\ originais e após investigação: análise de dois biênios nos anos 2000
}

Hellen Geremias dos Santos', Selma Maffei de Andrade', Ana Maria Rigo Silva', Wladithe Organ de Carvalho', Arthur Eumann Mesas', Alberto Durán González'

\begin{abstract}
Objective: To analyze the agreement between underlying causes of infant deaths obtained from Death Certificates (DC) with those defined after investigation by the Municipal Committee for the Prevention of Maternal and Infant Mortality (CMPMMI), in Londrina, Paraná State, in the biennia 2000-2001 and 2007-2008. Methods: DC of infants and records of investigations were obtained from the CMPMMI. The causes of death registered in both sources were coded according to the International Classification of Diseases, tenth revision (ICD-10), and the underlying causes of deaths were selected. Agreement between underlying causes of deaths was verified by Kappa's (k) test and analyzed according to ICD-10 chapters and blocks of categories in both biennia. Results: In 2000/2001, according to ICD-10 chapters, high agreement rates were observed for conditions originated in the perinatal period $(\mathrm{k}=0.85)$ and for external causes $(\mathrm{k}=0.84)$, while, for congenital malformations, there was a substantial agreement $(\mathrm{k}=0.71)$. In $2007 / 2008$, agreement was considered poor for all analyzed chapters. For blocks of categories, high or substantial agreement rates were observed only in the first biennium for "congenital malformations of the circulatory system" $(\mathrm{k}=0.78)$ and for "other external causes of accidental injury" $(\mathrm{k}=0.91)$. Conclusions: A decrease in agreement between the sources during the study period indicates either an improvement in the process of investigation of infant death by the CMPMMI and/or a worsening in the quality of the DC information.
\end{abstract}

Keywords: Infant mortality. Underlying cause of death. Death certificates. Information systems. Reproducibility of results.

Postgraduation Program in Collective Health, Universidade Estadual de Londrina - Londrina (PR), Brazil.

Corresponding author: Hellen Geremias dos Santos. Postgraduation Program in Collective Health. Avenida Robert Koch, 60, Vila Operária, CEP: 86038-350, Londrina, PR, Brazil. E-mail: hellengeremias@gmail.com

Conflict of interests: nothing to declare - Financial support: Decit/SCTIE/MS by means of the National Council of Technological and Scientific Development (CNPq) and Fundação Araucária (Call 08/2009 of Fundação Araucária), technical support scholarship to Fundação Araucária, Master's degree scholarship to CAPES, research productivity scholarship to CNPq. 
RESUMO: Objetivo: Analisar a concordância entre a causa básica de morte infantil informada na Declaração de Óbito (DO) e a definida após investigação pelo Comitê Municipal de Prevenção da Mortalidade Materna e Infantil (CMPMMI), em Londrina, Paraná, nos biênios 2000/ 2001 e 2007 / 2008. Método: Foram obtidas as DO e as fichas de investigação do CMPMMI de óbitos infantis. As causas de morte informadas em ambos os documentos foram transcritas para um formulário, sendo posteriormente codificadas segundo a Classificação Internacional de Doenças, décima revisão (CID-10), com seleção das respectivas causas básicas. As concordâncias entre as causas básicas das DO e as do CMPMMI foram verificadas pelo teste Kappa (k), para capítulos e agrupamentos da CID-10, em ambos os períodos. Resultados: Em 2000/2001, observou-se ótima concordância para o capítulo das afecções do período perinatal $(\mathrm{k}=0,85)$ e para o das causas externas $(\mathrm{k}=0,84)$, e boa concordância para o das malformações congênitas $(k=0,71)$. Em 2007/2008, a concordância entre os registros da DO e os do CMPMMI foi considerada ruim ou fraca para todos os capítulos de causas. Em relação aos agrupamentos, observou-se concordância boa ou ótima apenas no primeiro biênio para "malformações do aparelho circulatório" $(\mathrm{k}=0,78)$ e "outras causas externas acidentais" ( $\mathrm{k}=0,91)$. Conclusão: Observou-se diminuição da concordância entre as fontes pesquisadas no período estudado, o que indica melhora do processo de investigação dos óbitos infantis pelo CMPMMI e/ou piora na qualidade da informação original na DO.

Palavras-chave: Mortalidade infantil. Causa básica de morte. Declaração de óbito. Sistemas de informação. Reprodutibilidade dos testes.

\section{INTRODUCTION}

The underlying cause of death constitutes one of the most important information for the evaluation of health programs and for analyses of temporal tendencies and geographic differences in mortality ${ }^{1}$. All causes that result in death should be described in the Death Certificate (DC) by the physician who assisted the deceased in deaths due to natural causes, and by the legist in accidental or violent causes. The record of these causes should follow a logical and temporal sequence of morbid events since the initial (natural or external) until the final cause, which resulted directly in death. The underlying cause of death refers to the disease or kind of accident or violence responsible for the beginning of this process (initial cause) ${ }^{2}$.

Infant mortality analysis according to the underlying cause of death is essential for preventing infant death, because it allows directing actions to prevent the initial causes of the process that lead to death ${ }^{1}$. Nevertheless, indication of diseases that directly caused the death (final cause) or acted as mediators between the initial and final causes, without mentioning the underlying cause of death, is usual in the DC.

Several studies have assessed the quality of information about underlying causes of infant death described in the $\mathrm{DC}^{3-9}$. Comparisons between the causes originally reported in statements with those defined after investigation in hospital records, in results of medical autopsies, and in interviews with relatives represent the most used kinds of evaluation. 
Records of Infant Death Prevention Committees are still not very used as source of data for studies on mortality. The absence of such committees all over the national territory, the unavailability of a national information system including these records and making them electronically available, and difficulties associated with the organization of committees and with surveillance of all the infant deaths are considered possible limitations ${ }^{10,11}$. However, when the committees are properly structured, they collaborate in comprehending the circumstances of infant deaths and enabling improvements in the quality of statistics on mortality ${ }^{10,12-14}$.

In Londrina, Paraná, Brazil, the Municipal Committee for the Prevention of Maternal and Infant Mortality (MCPMIM) was created in 1999 and since then has been improving its actions on the investigation of infant and women of childbearing age deaths. The process of this investigation comprehends interviews with families and/or health professionals and referrals to hospital and ambulatory records from Health Basic Unities (HBU) or from the Institute of Forensic Medicine (IML, acronym in Portuguese). Londrina is the $38^{\text {th }}$ most populous town in Brazil and has one of the lowest rates of infant mortality (9.54 per a thousand live births in 2011). However, in absolute numbers of deaths, it occupies the $66^{\text {th }}$ position amongst more than 5 thousand Brazilian towns ${ }^{15}$.

In the end of 2001, there was an expansion of the Family Health Strategy (FHS) to the urban area of Londrina, reaching around $70 \%$ of the population inhabiting such area ${ }^{16}$. Based on the context of extending basic attention access, on the existence of an active MCPMIM, and on the importance of studies assessing the quality of information about causes of infant death, the present research had as its aim to analyze the agreement between the underlying cause of infant death reported in the DC and that established after investigation by the MCPMIM, in the biennia 2000/2001 and 2007/2008. Identifying changes in the quality standard of such information collaborates for understanding the process of information production about mortality and for adopting actions aiming its qualification.

\section{METHODOLOGY}

The study was carried out in Londrina, Paraná, Brazil, which is a town that had a population of 506,645 residents in $2010^{17}$. Two biennia from 2000 were researched: one after the creation of MCPMIM and before the FHS expansion to the urban area of the town (2000/2001), and another representing the most recent period (2007/2008), with data available about infant death at the moment of data collection.

The sources of data for the research were DC of children younger than one year old who lived in Londrina and investigation records of infant death from the MCPMIM. Initially, infant deaths of both biennia registered in the Mortality Information System (MIS) were identified and, later, by means of a manual research in MCPMIM files the DC and investigation cards of death with correction of the death causes were obtained. Causes reported in both documents were transcribed to a form with a structure that is similar to that of the DC, keeping the causal sequence informed in such documents.

The underlying causes of death were defined by an investigator qualified in Underlying Cause Selection with the support of the Underlying Cause Selection (UCS) program from 
the Brazilian Ministry of Health (MH). Then they were codified based on the International Statistics Classification of Diseases and Health-Related Problems, Tenth Revision (ICD-10). Posteriorly, the causes were typed on a spreadsheet of Microsoft Excel program, and grouped by chapters and groupings of the ICD-10.

In the analysis, the profiles of underlying causes of infant death by ICD-10 chapters were compared before and after death investigation through calculation of the relative frequency and Percentage Variation (PV). PV refers to the percentage difference between the absolute number of deaths in every chapter of the ICD-10 before $(\mathrm{x})$ and after investigation (y). It was calculated for each biennium through the following formula: $\left[(\mathrm{y}-\mathrm{x})^{\star} 100\right] / \mathrm{x}$.

Agreement between the underlying cause of the DC and that reported by the MCPMIM was analyzed for the chapters and groupings of the ICD-10. In order to measure such agreements, Kappa's test (k) and 95\% confidence intervals (95\% CI) were used and calculated in the WinPepi 3.06 program. The classification suggested by Landis Jr. and Koch adapted by Pereira ${ }^{18}$ was applied to interpret Kappa's test: $\mathrm{k}$-value $<0.00$ (bad agreement), from 0.00 to 0.20 (weak), from 0.21 to 0.40 (poor), from 0.41 to 0.60 (regular), from 0.61 to 0.80 (good), from 0.81 to 0.99 (great), and equal to 1.00 (perfect).

The study was approved by the Research Ethics Committee of Universidade Estadual de Londrina.

\section{RESULTS}

A total of 198 and 148 deaths of children younger than one year old, living in Londrina, was identified at the MIS in 2000/2001 and in 2007/2008. The MCPMIM investigated $97 \%$ of the deaths from the first biennium and $100 \%$ from those in the second. The main causes, according to ICD-10 chapters, were not changed after investigation in both biennia. However, the increase of death due to infectious and parasitic diseases, congenital malformations, and external causes is more seen. On the other hand, there was a decrease of deaths due to respiratory system diseases, affections originated in the perinatal period (APP), and ill-defined causes (Table 1).

In 2000/20001 around $90 \%$ of the deaths due to APP, congenital malformations, and external causes presented the same chapter after an investigation was conducted by the MCPMIM (Table 2).

In $2007 / 2008$, all deaths due to external causes, more than half due to congenital malformations, and around one third of those due to APP had an underlying cause changed to one of a different chapter after investigation (Table 3).

The concordance analysis by registration pairs, in the first studied biennium, showed great agreement for the chapters APP $(\mathrm{k}=0.85)$ and external causes $(\mathrm{k}=0.84)$, and good for congenital malformations $(\mathrm{k}=0.71)$. In $2007 / 2008$, it was observed a decrease in the agreement between DC and the MCPMIM records, the latter was considered bad or weak for all chapters about causes (Table 4).

ICD-10 grouping analysis revealed high frequency of deaths with a modified underlying cause, but still remaining in the same chapter. The chapters of the APP in the two biennia ( 66 changed 
Table 1. Distribution of infant deaths according to underlying cause of death described in death certificate and in Municipal Committee for the Prevention of Maternal and Infant Mortality records, according to chapters of ICD-10, Londrina, Paraná State, Brazil, 2000/2001 and 2007/2008.

\begin{tabular}{|c|c|c|c|c|c|c|c|c|c|c|}
\hline \multirow{3}{*}{ ICD-10 Chapters } & \multicolumn{5}{|c|}{$2000 / 2001$} & \multicolumn{5}{|c|}{$2007 / 2008$} \\
\hline & \multicolumn{2}{|c|}{ DC } & \multicolumn{2}{|c|}{ MCPMIM } & \multirow{2}{*}{$\mathrm{PV}^{*}$} & \multicolumn{2}{|c|}{ DC } & \multicolumn{2}{|c|}{ MCPMIM } & \multirow{2}{*}{$\mathrm{PV}^{*}$} \\
\hline & $\mathrm{n}$ & $\%$ & $\mathrm{n}$ & $\%$ & & $\mathrm{n}$ & $\%$ & $n$ & $\%$ & \\
\hline $\begin{array}{l}\text { I - Infectious and parasitic } \\
\text { diseases }\end{array}$ & 7 & 3.6 & 8 & 4.2 & +14.3 & 2 & 1.4 & 6 & 4.1 & +200.0 \\
\hline X- Respiratory system diseases & 9 & 4.7 & 3 & 1.6 & -66.7 & 5 & 3.4 & 2 & 1.4 & -60.0 \\
\hline $\begin{array}{l}\mathrm{XVI} \text { - Affections originated in the } \\
\text { perinatal period }\end{array}$ & 109 & 56.8 & 107 & 55.7 & -1.8 & 89 & 60.1 & 88 & 59.5 & -1.1 \\
\hline XVII- Congenital malformations & 37 & 19.3 & 48 & 25.0 & +29.7 & 38 & 25.7 & 42 & 28.4 & +10.5 \\
\hline XVIII- Ill-defined causes & 9 & 4.7 & 5 & 2.6 & -44.4 & 3 & 2.0 & 1 & 0.7 & -66.7 \\
\hline XX- External causes & 12 & 6.3 & 14 & 7.3 & +16.7 & 6 & 4.1 & 7 & 4.7 & +16.7 \\
\hline Others ${ }^{\#}$ & 9 & 4.7 & 7 & 3.6 & -22.2 & 5 & 3.4 & 2 & 1.4 & -60.0 \\
\hline
\end{tabular}

*Percentage variation (\%) CMPMMI/DC. CMPMMI: Municipal Committee for the Prevention of Maternal and Infant Mortality; DC: death certificate.

"Chapters: II - Neoplasms; IV - Endocrine, nutritional, and metabolic diseases; VI - Diseases of the nervous system;

IX - Diseases of the circulatory system; XI - Diseases of the digestive system; XIV - Diseases of the genitourinary system.

Table 2. Comparison between the underlying causes of death described in the death certificate and in the Municipal Committee for the Prevention of Maternal and Infant Mortality records according to chapters of ICD-10, Londrina, Paraná State, Brazil, 2000/2001.

\begin{tabular}{l|c|c|c|c|c|c|c|c|}
\hline \multirow{2}{*}{$\begin{array}{l}\text { Death } \\
\text { Certificate }\end{array}$} & \multirow{2}{*}{ Total } & \multicolumn{6}{|c|}{ Reallocation in each chapter after investigation by the MCPMIM } \\
\cline { 3 - 10 } & & $\begin{array}{c}\text { Chapter } \\
\text { I }\end{array}$ & $\begin{array}{c}\text { Chapter } \\
\text { X }\end{array}$ & $\begin{array}{c}\text { Chapter } \\
\text { XVI }\end{array}$ & $\begin{array}{c}\text { Chapter } \\
\text { XVII }\end{array}$ & $\begin{array}{c}\text { Chapter } \\
\text { XVIII }\end{array}$ & $\begin{array}{c}\text { Chapter } \\
\text { XX }\end{array}$ & Others \\
\hline Chapter I & 7 & 5 & 1 & - & 1 & - & - & - \\
\hline Chapter X & 9 & 1 & 2 & 2 & 3 & - & - & 1 \\
\hline Chapter XVI & 109 & - & - & 101 & 6 & - & 2 & - \\
\hline Chapter XVII & 37 & - & - & 3 & 33 & - & - & 1 \\
\hline Chapter XVIII & 9 & 1 & - & 1 & 1 & 5 & 1 & - \\
\hline Chapter XX & 12 & - & - & - & - & - & 11 & 1 \\
\hline Others & 9 & 1 & - & - & 4 & - & - & 4 \\
\hline Total & 192 & 8 & 3 & 107 & 48 & 5 & 14 & 7
\end{tabular}

MCPMIM: Municipal Committee for the Prevention of Maternal and Infant Mortality; CD: cause of death.

"Chapters: 1 - Certain infectious and parasitic diseases; X - Diseases of the respiratory system; XVI - Certain conditions originated in the perinatal period; XVII - Congenital malformations, deformations and chromosomal abnormalities; XVIII - Symptoms, signs, and abnormal clinical and laboratorial findings, not elsewhere classified; XX - External causes of morbidity and mortality; Others: II - Neoplasms; IV - Endocrine, nutritional, and metabolic diseases; $\mathrm{VI}$ - Diseases of the nervous system; IX - Diseases of the circulatory system; XI - Diseases of the digestive system; XIV - Diseases of the genitourinary system. 
Table 3. Comparison between the underlying causes of death described in the death certificate and in the Municipal Committee for the Prevention of Maternal and Infant Mortality records according to chapters of ICD-10, Londrina, Paraná State, Brazil, 2007/2008.

\begin{tabular}{l|c|c|c|c|c|c|c|c}
\hline \multirow{2}{*}{$\begin{array}{l}\text { Death } \\
\text { Certificate }\end{array}$} & \multirow{2}{*}{ Total } & \multicolumn{6}{|c|}{ Reallocation in each chapter after investigation by the MCPMIM } \\
\cline { 2 - 9 } & & $\begin{array}{c}\text { Chapter } \\
\text { I }\end{array}$ & $\begin{array}{c}\text { Chapter } \\
\text { X }\end{array}$ & $\begin{array}{c}\text { Chapter } \\
\text { XVI }\end{array}$ & $\begin{array}{c}\text { Chapter } \\
\text { XVII }\end{array}$ & $\begin{array}{c}\text { Chapter } \\
\text { XVIII }\end{array}$ & $\begin{array}{c}\text { Chapter } \\
\text { XX }\end{array}$ & Others \\
\hline Chapter I & 2 & - & - & 1 & 1 & - & - & - \\
\hline Chapter X & 5 & - & - & 4 & 1 & - & - & - \\
\hline Chapter XVI & 89 & 5 & - & 57 & 20 & 1 & 5 & 1 \\
\hline Chapter XVII & 38 & 1 & 2 & 16 & 16 & - & 2 & 1 \\
\hline Chapter XVIII & 3 & - & - & 1 & 2 & - & - & - \\
\hline Chapter XX & 6 & - & - & 4 & 2 & - & - & - \\
\hline Others & 5 & - & - & 5 & - & - & - & - \\
\hline Total & 148 & 6 & 2 & 88 & 42 & 1 & 7 & 2
\end{tabular}

MCPMIM: Municipal Committee for the Prevention of Maternal and Infant Mortality.

"Chapters: 1 - Certain infectious and parasitic diseases; X - Diseases of the respiratory system; XVI - Certain conditions originated in the perinatal period; XVII - Congenital malformations, deformations and chromosomal abnormalities; XVIII - Symptoms, signs and abnormal clinical and laboratorial findings, not being elsewhere classified; XX - External causes of morbidity and mortality; Other: II - Neoplasms; IV - Endocrine, nutritional, and metabolic diseases;

$\mathrm{VI}$ - Diseases of the nervous system; IX - Diseases of the circulatory system; XI - Diseases of the digestive system; XIV - Diseases of the genitourinary system.

Table 4. Concordance (Kappa index) between the underlying cause of infant death before and after Municipal Committee for the Prevention of Maternal and Infant Mortality investigation, according to ICD-10 chapter, Londrina, Paraná State, Brazil, 2000/2001 and 2007/2008.

\begin{tabular}{l|c|c|c|c}
\multirow{2}{*}{ ICD-10 Chapters } & \multicolumn{4}{|c}{ Biennia } \\
\cline { 2 - 6 } & \multicolumn{2}{|c|}{$2000 / 2001$} & \multicolumn{2}{c}{$2007 / 2008$} \\
\cline { 2 - 6 } & Kappa & $95 \% \mathrm{Cl}$ & Kappa & $95 \% \mathrm{Cl}$ \\
\hline I- Infectious and parasitic diseases & 0.65 & $0.37-0.94$ & -0.02 & $-0.04-0.00$ \\
\hline X- Respiratory system diseases & 0.32 & $-0.03-0.66$ & -0.02 & $-0.04-0.00$ \\
\hline XVI - Affections originated in the perinatal period & 0.85 & $0.78-0.93$ & 0.11 & $-0.05-0.28$ \\
\hline XVII - Congenital malformations & 0.71 & $0.60-0.83$ & 0.18 & $0.01-0.35$ \\
\hline XVIII - IIl-defined causes & 0.70 & $0.43-0.98$ & -0.01 & $-0.03-0.01$ \\
\hline XX - External causes & 0.84 & $0.68-0.99$ & -0.05 & $-0.07--0.02$ \\
\hline Others & 0.48 & $0.17-0.79$ & -0.02 & $-0.04-0.00$
\end{tabular}

"Chapters: II - Neoplasms; VI - Endocrine, nutritional, and metabolic diseases; VI - Diseases of the nervous system;

IX - Diseases of the circulatory system; XI - Diseases of the digestive system; XIV - Diseases of the genitourinary system. 
underlying causes out of 101, in 2000/2001, and 35 out of 57, in 2007/2008) and of congenital malformations in the most recent period were the most emphasized. In them, all the deaths remaining in this chapter had their underlying causes changed after investigation (16 deaths).

Thus, it was possible to notice good or great concordance only in the first biennium and for the following groupings: "circulatory system malformations" (codes Q20 - Q28), $\mathrm{k}=0.78$ [95\%CI $0.62-0.95]$, and "other accidental external causes" (codes W00 - X59), $\mathrm{k}=0.91$ [95\%CI $0.79-1.00]$.

In 2000/2001, although agreement between the DC and MCPMIM has been great for the APP chapter, a weak concordance was seen for the "respiratory and cardiovascular disorders specific of the perinatal period" grouping (P20 - P29), $\mathrm{k}=0.10$, which changed from 46 to 6 causes after investigation. Also, a poor concordance for the "fetus or newborn affected by maternal factors and by complications of pregnancy, labor or delivery” grouping (P00 P04), $\mathrm{k}=0.29$, which changed from 28 to 86 causes after investigation.

Since agreement by ICD-10 chapters was already bad or weak in $2007 / 2008$, it was seen a similar tendency in the grouping analysis.

\section{DISCUSSION}

Studies on the quality of information about the underlying cause of infant death through a comparison between the original records and after a detailed investigation are still rare in Brazil. They can only be performed in local contexts, such as those carried out in Porto Alegre and Pelotas ${ }^{3}$, in metropolitan areas of Rio de Janeiro ${ }^{4}$ and Belo Horizonte ${ }^{5}$, Blumenau ${ }^{6}$, Montes Claros $^{8}$ or in specific services ${ }^{7,9}$. The results of the present study are in agreement with those from these investigations, because the concordance indices in general vary according to the ICD-10 chapter under analysis. In addition, more concordances have been described for the APP and congenital malformations chapters ${ }^{5,6,8,9}$.

In $2000 / 2001$, agreement indices were similar to the studies based only on the review of hospital records $s^{4-8}$, with great concordance for the APP and external causes' chapters, and good for the congenital malformations. However, Mendonça, Goulart and Machado $^{5}$ state that good agreement of causes by ICD-10 chapters, after investigating the process that ended up in death, happens by an internal compensation of disagreements. For example, in the APP chapter, even though there was a change of cause after the investigation, its permanence in this same chapter is still happening.

In fact, for the ICD-10 groupings, it was possible to see a weak agreement for "respiratory and cardiovascular disorders specific of the perinatal period" and for "fetus or newborn affected by maternal factors and by complications of pregnancy, of labor and of delivery", both from the APP chapter. This happened due to a decrease in indicating the first grouping and increase to the second after investigation. 
These results show that the Committee actuation enables more specificity of information about causes of infant deaths, because grouping concerning the maternal factors and pregnancy and labor complications is closer to the beginning of the chain of events that lead to death, and, therefore, to the underlying cause ${ }^{1,10}$ definition than to the respiratory and cardiovascular disorders of the newborn. The reduction of deaths due to mistaken causes and of those caused by diseases of the respiratory system reinforces the MCPMIM importance in classifying the underlying cause of death.

Weak or bad concordance indices were seen in 2007/ 2008 for all the analyzed chapters. Among the researched periods, there was an important extension of the number of teams acting in the FHS ${ }^{16}$. It is believed that such measure may have collaborated so that data survey about infant death occurrence through interviews with families and basic attention professionals, may have happened more effectively causing a positive impact in the specificity of the underlying cause of death described by the MCPMIM.

It is possible that the worsening in agreement indices in recent years happened due to the improvement in the infant death investigation process. However, one should also consider the possibility of quality worsening in the underlying cause of death reported in the DC. It is known that the quality of information recorded in the DC also depends on the access to health services, on technologies for diagnosis, and on the professional's technical capacity on recognizing the dynamic of events that participated in the causal chain of death, as well as of his/her behavior in producing reliable statistics ${ }^{8,19}$.

Studies concerning quality of information about death causes point out the nonincorporation of the underlying cause idea by physicians and the valorization of legal aspects opposed to the epidemiological ones as factors that contribute for the indication of generic or terminal death causes in the $\mathrm{DC}^{4,7}$. Great amount of DC fields, lack of information to establish diagnosis, and lack of instructions about completion of such document were other reasons reported by physicians of the partial and/or inconsistent fulfillment of the $\mathrm{DC}^{20}$. The certificate of death causes can still be subject to fads like the frequent use of terms such as "cardiac arrest" and "failure of multiple organs"

Hence, the qualification of physicians and Medicine students for the complete and coherent record of information in the DC is an essential measure to improve the quality of mortality statistics ${ }^{1,21,22}$. Infant Death Investigation Committees can collaborate in this meaning because they present in their attributions the sensitization of professionals to appropriately complete such records ${ }^{10,14}$.

\section{CONCLUSIONS}

Results show a decrease of agreement between the underlying cause information in the DC and that defined after investigation by the MCPMIM in the most recent biennium (2007/2008). This finding may seem to indicate improvement of the investigation 
process of infant deaths by the Committee. However, worsening of the quality of the original information in the DC cannot be discarded in the researched period. Therefore, studies assessing the reasons for this greater discordance in more recent years should be performed. Regardless of the need of more studies, the importance of adopting educational measures aiming at stimulating the correct completion of this document must be more emphasized ${ }^{1,8,21,22}$.

\section{REFERENCES}

1. Laurenti R, Mello Jorge MHP, Gotlieb SLD. Mortalidade segundo causas: considerações sobre a fidedignidade dos dados. Rev Panam Salud Publica 2008; 23: 349-56.

2. Brasil. Ministério da Saúde. Conselho Federal de Medicina. Centro Brasileiro de Classificação de Doenças. A declaração de óbito: documento necessário e importante. Disponível em: http: / portal.saude.gov.br/portal/ arquivos/pdf/declaracao_de_obitooo.pdf. (Acessado $1^{\circ}$ de abril de 2013).

3. Nobre LC, Victora CG, Barros FC, Lombardi C, Teixeira AMB, Fuchs SC. Avaliação da qualidade da informação sobre a causa básica de óbitos infantis no Rio Grande do Sul (Brasil). Rev Saude Publica 1989; 23: 207-13.

4. Carvalho ML, Niobey FM, Miranda NN, Sabroza PC. Concordância na determinação da causa básica de óbito em menores de um ano na região metropolitana do Rio de Janeiro, 1986. Rev Saude Publica 1990; 24: 20-7.

5. Mendonça EF, Goulart EM, Machado JAD. Confiabilidade da declaração de causa básica de mortes infantis em região metropolitana do sudeste do Brasil. Rev Saude Publica 1994; 28: 385-91.

6. Santa Helena ET, Rosa MB. Avaliação da qualidade das informações relativas aos óbitos em menores de um ano em Blumenau, 1998. Rev Bras Saúde Matern Infant 2003; 3: 75-83.

7. Vanderlei LC, Arruda BKG, Frias PG, Arruda S. Avaliação da confiabilidade da causa básica de óbito em unidade terciária de atenção à saúde maternoinfantil. Inf Epidemiol SUS 2002; 11: 15-23.

8. Soares JAS, Horta FMB, Caldeira AP. Avaliação da qualidade das informações em declarações de óbitos infantis. Rev Bras Saúde Matern Infant 2007; 7: 289-95.

9. Silva CM, Gomes KR, Rocha OA, Almeida IM, Moita Neto JM. Validade, confiabilidade e evitabilidade da causa básica dos óbitos neonatais ocorridos em unidade de cuidados intensivos da Rede Norte-Nordeste de Saúde Perinatal. Cad Saude Publica 2013; 29: 547-56.
10. Brasil. Ministério da Saúde. Secretaria de Atenção à Saúde. Departamento de Ações Programáticas. Manual de vigilância do óbito infantil e fetal e do Comitê de Prevenção do Óbito Infantil e Fetal. Disponível em: http:/ / portal.saude.gov.br/portal/ arquivos/pdf/Manual_Infantil_Fetal.pdf. (Acessado em 21 de janeiro de 2013).

11. Venâncio SI, Paiva R. O processo de implantação dos Comitês de Investigação do Óbito Infantil no Estado de São Paulo. Rev Bras Saúde Matern Infant 2010; 10: 369-75.

12. Silva CF, Leite AJ, Almeida NM. Linkage entre bancos de dados de nascidos vivos e óbitos infantis em município do Nordeste do Brasil: qualidade dos sistemas de informação. Cad Saude Publica 2009; 25: 1552-8.

13. Mathias TA, Assunção AN, Silva GF. Óbitos infantis investigados pelo Comitê de Prevenção da Mortalidade Infantil em região do Estado do Paraná. Rev Esc Enferm USP 2008; 42: 445-53.

14. Mansano NH, Mazza VA, Soares VM, Araldi MA, Cabral VL. Comitês de prevenção da mortalidade infantil no Paraná, Brasil: implantação e operacionalização. Cad Saude Publica 2004; 20: 329-32.

15. Departamento de Informática do Sistema Único de Sáude. Informações em saúde: estatísticas vitais. Disponível em: http: / / www2.datasus.gov.br/ DATASUS / index.php?area $=0205$. (Acessado em 9 de julho de 2013).

16. Secretaria Municipal de Saúde de Londrina. Autarquia Municipal de Saúde. Prefeitura de Londrina. Relatório de gestão 2002. Disponível em: http: / / www1.londrina. pr.gov.br/dados/images/stories/Storage/sec_saude/ relatorios_gestao/relatorio_gestao_2002.pdf. (Acessado em 21 de janeiro de 2013).

17. Instituto Brasileiro de Geografia e Estatística. Primeiros Dados do Censo 2010. Disponível em: http: / / www. ibge.gov.br/home/estatistica/populacao/censo2010/ primeiros_resultados/populacao_por_municipio. shtm. (Acessado em 31 de março de 2010). 
18. Pereira MG. Epidemiologia: Teoria e Prática. Rio de Janeiro: Guanabara Koogan; 1995.

19. Hernandez B, Ramirez-Villalobos D, Romero M, Gomez S, Atkinson C, Lozano R. Assessing quality of medical death certification: Concordance between gold standard diagnosis and underlying cause of death in selected Mexican hospitals. Popul Health Metr 2011; 9: 38.

20. Mendonça FM, Drumond E, Cardoso AMP. Problemas no preenchimento da Declaração de Óbito: estudo exploratório. Rev Bras Estud Popul 2010; 27: 285-95.
21. Degani AT, Patel RM, Smith BE, Grimsley E. The effect of student training on accuracy of completion of death certificates. Med Educ Online 2009; 14: 17.

22. Madsen A, Thihalolipavan S, Maduro G, Zimmerman R, Koppaka R, Li W, et al. An intervention to improve cause-of-death reporting in New York City hospitals, 2009-2010. Prev Chronic Dis 2012; 9: E157.

Received on: 08/19/2013

Accepted on: 11/13/2013 